\author{
YARATICILIK VE TASARIM ARAÇLARI: ÜRÜN FİKIIRLERİ \\ YARATIMINDA BILGISAYAR DESTEKLII TASARIM VE EL ESKIZİ \\ ARAÇLARININ KARŞILAŞTIRILMASI ${ }^{1}$
}

\title{
CREATIVITY AND DESIGN TOOLS: COMPARISON OF COMPUTER- AIDED DESIGN AND HAND SKETCHING TOOLS IN GENERATING PRODUCT IDEAS
}

\author{
Merve COŞKUN $N^{1}$, Barış GÜR $R^{2}$, Abdullah TOĞAY \\ ${ }^{1-2-3}$ Gazi University, Faculty of Architecture, Ankara / Turkey
}

ORCID ID: 0000-0002-0402-3061 ${ }^{1}, 0000-0003-4177-1656^{2}, 0000-0002-8703-4881^{3}$

\begin{abstract}
Öz: Amaç: Çalışmanın amacı ürün tasarımı sürecinin fikir geliştirme aşamasında 3 boyutlu Bilgisayar Destekli Tasarım (BDT) modelleme araçlarının kullanımının tasarımcının yaratıcılığına etkilerini araştırmaktır. Yöntem: Bireylerin yaratıcilığını ölçmek için kullanılan Torrance Yaratıcı Düşünce Testi’nin yaklaşımından esinlenerek tasarlanan iki aşamalı ampirik çalışma 20 tasarımcının katılımı ile gerçekleştirilmiştir. Katılımcılardan, ilk aşamada el eskizi, ikinci aşamada 3 boyutlu modelleme kullanarak verilen iki ürün tanımı için ürün fikirleri geliştirmeleri istenmiştir. Geliştirilen ürün fikirleri, Guilford'un üç yaratıcılık ölçütü (esneklik, özgünlük ve detaylandırma) göz önünde bulundurularak 20 tasarım uzmanı tarafından karşılaş̧ırmalı olarak değerlendirilmiştir. Değerlendirmeler arasındaki farkın önemine ilişkin bulguları analiz etmek için Wilcoxon işaretli sıralama testi yapılmıştır. Ayrıca, ampirik çalışmanın sonuçlarını yorumlarken destek sağlaması için bir anket uygulanmıştır. Bulgular: Sonuçlar, el çizimi ile oluşturulan fikirlerin BDT modellemesi ile elde edilen fikirlere göre daha esnek ve orijinal olarak değerlendirildiğini, ancak Wilcoxon İşaretli Sıralar Testi'nin sonuçları, uzmanların değerlendirmesi arasında istatistiksel olarak anlamlı bir fark olmadığını göstermiştir. Bu nedenle, fikir üretme aşamasındaki BDT araçlarının kullanımının her tasarımcıyı esneklik ve özgünlük açısından farklı şekilde etkileyebileceği sonucuna varılmıştır. Ancak ayrıntılandırma ölçütü açısından BDT araçlarının olumlu etkisi olduğu gözlemlenmiştir. Sonuç: Bu çalışma, bilgisayar destekli modellemenin yaratıcilığı hem olumlu hem de olumsuz yönde etkileyebileceğini göstermiştir. El eskizinin esneklik ve özgünlük boyutları üzerinde olumlu etkisi saptanırken, bilgisayar destekli modellemenin katılımcıların çoğunun ayrıntılandırma becerilerini artırdığı gözlemlenmiştir.

Anahtar Kelimeler: Ürün Tasarımı, Bilgisayar Destekli Tasarım (BDT), 3 Boyutlu Modelleme, Yaratıcılık, Fikir Üretme
\end{abstract}

Abstract: Aim: The aim of the study is to investigate the influence of using 3D Computer-Aided Design (CAD) modeling tools in the idea generation phase of the product design process on designer's creativity. Method: The two-stage empirical study inspired by the Torrance Test of Creative Thinking used to measure the creativity of individuals was conducted with the participation of 20 new generation designers. Participants were asked to develop ideas for two product definitions by using hand sketching for the first stage and $\mathrm{CAD}$ modeling for the second. The product ideas generated were evaluated comparatively by 20 design experts considering Guilford's three creativity measures: flexibility, originality, and elaboration. Wilcoxon signed-rank test was performed to analyze the finding regarding the significance of the difference between evaluations. In addition, a questionnaire was conducted to provide support while interpreting the results of the empirical work. Results: The results indicated that ideas generated by hand sketching were evaluated more flexible and original compared with the ideas by CAD modeling, however, the results of the Wilcoxon Signed Ranks Test showed that there were no statistically significant differences between the experts' evaluations. Therefore, it was concluded that $\mathrm{CAD}$ usage in idea generation phase could affect each designer differently in terms of flexibility and originality. But in terms of elaboration measure, it was observed that using CAD modeling has a positive influence. Conclusion: This study showed that the use of CAD modeling could affect creativity in both a positive and negative way. While the use of hand sketching has a positive effect on flexibility and originality dimensions, it was observed that the use of CAD modeling increased elaboration skills of most of the participants.

Key Words: Product Design, Computer-Aided Design (CAD), 3D Modeling, Creativity, Idea Generation

Doi: $10.17365 / T M D .2018 .3 .8$

(1) Corresponding Author: Merve COŞKUN, Gazi University, Faculty of Architecture, Ankara / Turkey, mervesarisin@gmail.com, Geliş Tarihi: Received: 25.07.2018 - Kabul Tarihi: Accepted: 13.12.2018 Makalenin Türü: Typeofarticle (Araştırma - Inceleme / Research Examination) Çıkar Çatışmast - Conflict of Interest: Yok / None "Etik Kurul Raporu Yok - None of Ethics Commit 
www.mtddergisi.com

ULUSLARARASI HAKEMLİ TASARIM VE MIMARLIK DERGISII

Eyül / Ekim / Kasım / Aralık Yıl: 2018 Sayı: 15 Sonbahar Kıș Dönemi

INTERNATIONAL REFEREED JOURNAL OF ARCHITECTURE AND DESIGN

September / October / November / December Year: 2018 Number: 15 Autumn Winter Semester ID:324 K:433

ISSN Print: 2148-4880 Online: 2148-8142

(ISO 18001-OH-0090-13001706 / ISO 14001-EM-0090-13001706 / ISO 9001-QM-0090-13001706 / ISO 10002-CM-0090-13001706) (Marka Patent No / Trademark)

(2015/04018 - 2015/GE/17595)

\section{INTRODUCTION}

Over the past fifty years, the developments observed in applied information technologies have caused significant alteration in product design. As one of the most influential technologies, computer-aided design (CAD) has changed the face of the design practice. During the early years of the CAD technology, it was primarily viewed by designers as a useful method of producing final presentations and production drawings. Since then, with the continuing development of technology, CAD has moved from a peripheral component of design activity to a central tool in the design process (Unver, 2006: 324), which has evolved into a hybrid process where digital technologies and traditional methods (sketches, drawings, models) are used together (Yıldirım, et al., 2011: 18). The use of 3-dimensional CAD modeling tools had mainly been restricted to the later stages of design process such as modeling of parts and assemblies, inspection, detailing, preparation for manufacturing, finite element analysis, simulation, etc. (Marzal, et al., 2012: 264). Along with these tools have become far more flexible over time, they have begun to be used as a tool for developing and exploring ideas in the early stages of product design process rather than just as a tool for detailing and representation (Won, 2001: 320).

Product design calls for new, integrated solutions to complex, multidisciplinary real- world problems. These problems are generally ill-defined and ill-structured (Cross, 2006: 7). Unlike well-defined problems, analyzing all the necessary information does not guarantee to find the perfect solution for design problems. In order to cope with the ill-defined problems and find the right solution for the client, designers need to define, redefine and change the design problem; and adopt constructive and creative problem-solving strategies based on generating and testing potential solutions (Cross, 2006: 18). Therefore, creativity is one of the most expected characteristics of a designer.

\section{RESEARCH PROBLEM}

The influence of using CAD as a designing tool on designer's creativity is still a controversial issue for both educators and practitioners in the discipline. The widespread belief in this regard is that the use of CAD modeling tools as a means of designing is likely to reduce the speed and efficiency of the process, negatively affect the creative production of designers especially for the early stages of design process (Lawson, 1997: 281-285; Gedenryd, 1998: 4, Bilda, et al., 2003: 49; Utterback, 2006: 215-227; Charlesworth, 2007: 35-45; Robertson, et al., 2007: 753-760; Robertson et al., 2009: 136-146; Stones, et al., 2010: 439-460, 2010; Veisz, et al., 2012: 5-8; Häggman, et al., 2015:1-12). However, CAD tools have become far more flexible 
and easy to use over time. Today, they have become commonly used tools in the early stages of product design processes where creative thinking is most needed. Depending on the fact that creativity is a result of multiple creativeness measures, this study focuses on how the use of different design tools affects creativity in the idea generation phase of the design process.

\section{AIM}

The aim of the study is to investigate the influence of using 3D CAD modeling tools in the idea generation phase of the product design process on designer's creativity. This study aims to provide empirical findings to clarify how the use of CAD tools affects creativity that is addressed as a combination of multiple measures in the context of this study.

\section{SCOPE}

In accordance with this aim, the scope of the paper covers the background related to the discussion concerning the link between designing tools and creativity and the discussion how the degree of creativity can be measured with the help of the psychology literature. This is followed by the empirical study which investigated the relationship between
CAD and creativity with a semi-experimental approach. It is believed that the results of this work will be useful in positioning CAD tools in current design education and practice.

\section{THEORETICAL FRAMEWORK}

\section{Idea Generation/Concept Design Phase of the Product Design Process}

The design process is "the overall workflow by which the actions of an industrial designer are performed" (Industrial Design Institute, 2014: 16) and it starts with the definition of product and continues until the product is ready for production. There are many design process models in the literature that are similar in general structure but differ only in details. For example, Industrial Design Institute (2014: 16) offers a five-stage process model that includes definition (where the product requirements are defined), research (where design team gain insight related to design problem), conceptualization (where ideas/ concepts are developed and presented), iteration (where the concept goes through cycles of design and refinement) and production. Cross's simplified model of the design process consists of 4 main stages as exploration, generation, evaluation, and communication (Figure 1). 


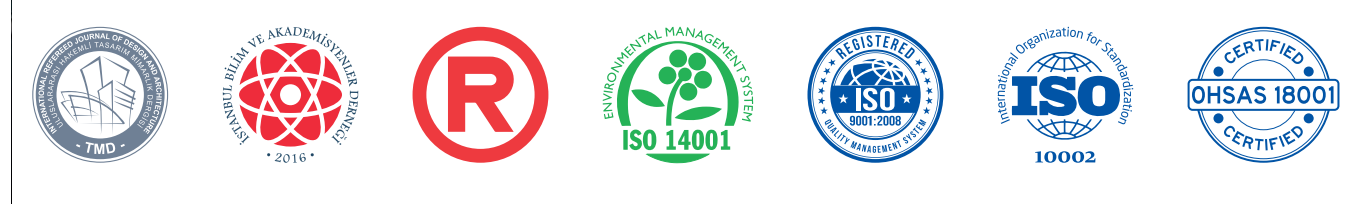

MTD

www.mtddergisi.com

ULUSLARARASI HAKEMLİ TASARIM VE MIMARLIK DERGISİ

Eyül / Ekim / Kasım / Aralık Yıl: 2018 Sayı: 15 Sonbahar Kış Dönemi

INTERNATIONAL REFEREED JOURNAL OF ARCHITECTURE AND DESIGN

September / October / November / December Year: 2018 Number: 15 Autumn Winter Semester

ID:324 K:433

ISSN Print: 2148-4880 Online: 2148-8142

(ISO 18001-OH-0090-13001706 / ISO 14001-EM-0090-13001706 / ISO 9001-QM-0090-13001706 / ISO 10002-CM-0090-13001706)

(Marka Patent No / Trademark)

(2015/04018 - 2015/GE/17595)

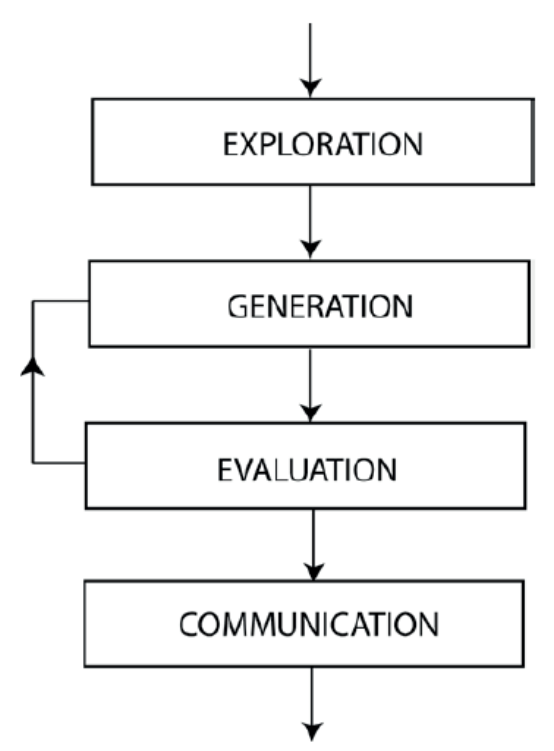

Figure 1. Cross' Simplified Model of the Design Process (Cross, 2005: 30)

The model of Self (2011: 64) was formed by reviewing the existing process models in detail and based upon the responsibilities of the industrial designer. According to the model (Figure 2.), product design process has three generic phases as concept design, development design, and detail design. Concept design is the phase in which design problems are identified and a large number of solution ideas are produced with a divergent approach
(Cross, 2005: 31). Many potential product ideas are created and the most likely ideas are selected to be considered in more detail in the development design phase according to the determined objectives. The concept design phase consists of generating ideas through the search, creation and selection of concepts appropriate to the design spesifications (Pahl and Beitz, 2007: 57). 


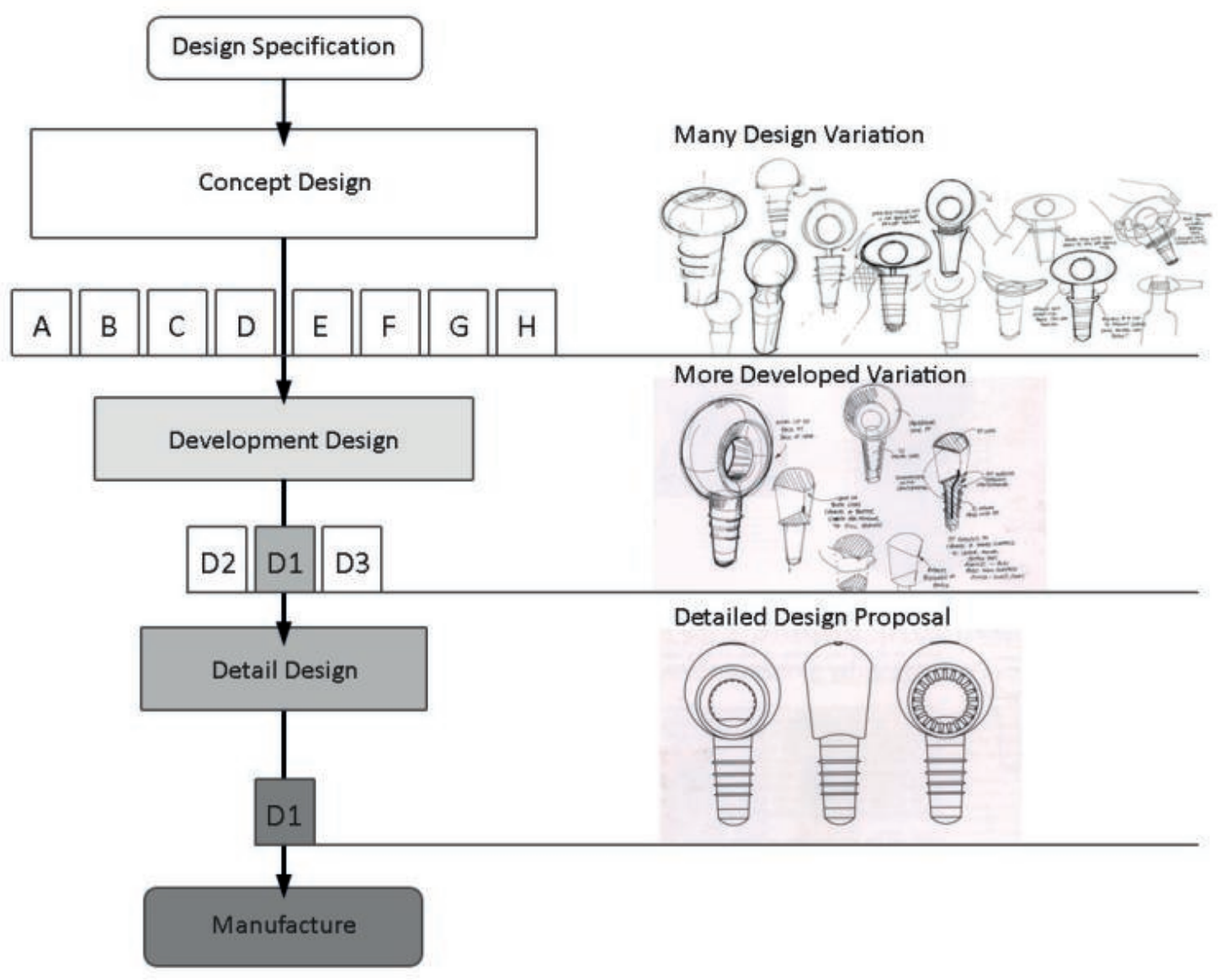

Figure 2. Model of the Industrial Design Process (adapted from Self, 2011: 64)

\section{Design Tools: Hand Sketching vs CAD}

There are many different design tool used in the design process. They can be examined under 3 general headings as analog (e.g. hand sketching, hand drawing, illustrations, mockup, model making), digital (e.g. CAD, digital modelling, digital illustration and rapid prototyping) and hybrid tools (e.g. haptic devices, graphics tablets) (Self, 2011: 91). Since this study focuses on the idea generation by us- ing hand sketching and CAD modeling, these two will be discussed in detail in the following paragraphs.

Hand sketching, as the most common way of externalization of ideas, is an indispensable media for designers particularly for concept design phase. It is important to distinguish idea sketching from presentation drawings/ renderings. A sketch is a kind of visual design representation that is created quickly and 
www.mtddergisi.com

ULUSLARARASI HAKEMLİ TASARIM VE MIMARLIK DERGISİ

Eyül / Ekim / Kasım / Aralık Yıl: 2018 Sayı: 15 Sonbahar Kıș Dönemi

INTERNATIONAL REFEREED JOURNAL OF ARCHITECTURE AND DESIGN

September / October / November / December Year: 2018 Number: 15 Autumn Winter Semester ID:324 K:433

ISSN Print: 2148-4880 Online: 2148-8142

(ISO 18001-OH-0090-13001706 / ISO 14001-EM-0090-13001706 / ISO 9001-QM-0090-13001706 / ISO 10002-CM-0090-13001706) (Marka Patent No / Trademark)

(2015/04018 - 2015/GE/17595)

roughly and often does not contain product details. Compared with sketches, drawings are more structured in order to formalize and verify certain aspects of a design (Goel, 1995: 197). Idea sketching is an exploratory activity that can be described as a visual dialogue between designer and output or an argument between opposing points of view (Temple, 1994: 16-25). With its flexible nature, it encourages intuitive interactions and enables designer to transfer product ideas to herself/himself and others. As the fastest and the most effective communication tool, it is used "to get the design concept out of one head and into another" (Tovey, et al., 1996: 63). Buxton (2007: 111) lists the main characteristics of sketches as follows: quick, timely, inexpensive, disposable, plentiful and ambiguous. Ambiguity is considered to be the most essential feature of sketching that can increase flexibility, spontaneity and creativity by allowing transformation and reinterpretation (Stones \& Cassidy, 2010: 442-444). Utterback (2006: 215) also pointed out the same phenomenon and expressed as the inexactness of the sketching. Because it's fuzzy, unclear and unfinished nature, the exact same sketch may not signify the same meaning to different observers or the same observer at a different time. This makes it possible to see and re-examine the same sketch with a different eye. The process of re-examination can lead to unexpected discoveries that generate new ideas and solutions through new sketches from previous ones (Suwa, et al., 2002: 102). Another important characteristic of sketching is that it concentrates on essentials rather than details (Stones \& Cassidy, 2010: 440). As Marzal et. al. (2012: 265) pointed out, while sketching, designers focus on general aspects of the design; define firstly major principles and then refine the drawings adding detail when needed.

Since the early 1990s CAD has become widely used design tool as a consequence of its ability to provide fast reiteration of design proposals (Charlesworth, 2007: 36). With 3D CAD modeling tools, designers are able to create, edit, copy, scale, mirror lines and shapes quickly and easily. While some software has a digital sculpting ability such as Fusion 360, 3DS max, Z-Brush which is very close to hand sketching in terms of form exploration, some software works with a more structured parametric logic like Solidworks, Alias, etc. According to Brown (2009: 53), the most distinctive features of CAD is the capability to create complex drawings of a concept that can even be used as the blueprint for the product's eventual manufacturing. Shortening the analysis and synthesis time, performing complex calculations more accurately and faster, shortening the total drawing time, creating more design options and evaluating different solution alternatives 
MTD

www.mtddergisi.com

ULUSLARARASI HAKEMLİ TASARIM VE MIMARLIK DERGISI

Eyül / Ekim / Kasım / Aralık Yıl: 2018 Sayı: 15 Sonbahar Kış Dönemi

INTERNATIONAL REFEREED JOURNAL OF ARCHITECTURE AND DESIGN

September / October / November / December Year: 2018 Number: 15 Autumn Winter Semester ID:324 K:433

ISSN Print: 2148-4880 Online: 2148-8142

(ISO 18001-OH-0090-13001706 / ISO 14001-EM-0090-13001706 / ISO 9001-QM-0090-13001706 / ISO 10002-CM-0090-13001706) (Marka Patent No / Trademark)

(2015/04018-2015/GE/17595)

can be listed as the most important capabilities of CAD. These capabilities of CAD have made manufacturing more time and cost efficient therefore the use of CAD software in the design process is most widely supported by industry (Brown, 2009: 54). Unver (2006: $325)$ claimed that $\mathrm{CAD}$ allows designers to be more than just stylists by increasing the parameters that designers dominate, enabling them to have a more effective role in the product development process, from concept to manufacturing while deepening the understanding of final form, structure and performance of a product.

Warburton (1996: 22-27) states that there is no need for digital support in the conceptual design phase however she suggests that using computer aided modeling becomes beneficial and effective during the later stages of industrial design activity i.e. design validation, design specifications and communication. Bilda and Demirkan (2003: 27-50) conclude in an experiment on architectural design that using traditional sketching has more advantages over digital media in terms of production of alternative solutions and better conception of the design problem. In an empirical experiment with graphic design students, Stones and Cassidy (2010: 439-460) found that paper-based sketching supports the process of reinterpretation that creates new solutions more than digital tools. According to the findings of the case study conducted by Robertson, et al. (2007: 753-760), questioning the influences of the use of CAD tools on creative processes of engineering designers, three different kinds of negative effects were described as circumscribed thinking, bounded ideation, premature fixation. Circumscribed thinking refers that the CAD tool has too strong influence over the design process either by limiting the design alternatives that can be created in the process, or by encouraging the designer to cope with unnecessary complexities due to provide too much freedom. Bounded ideation was observed when the constant use of CAD tools decreases the designers' motivations and creative problem solving abilities. Premature fixation can occur when the CAD model become a certain level of complexity with a large amount of details. Designer becomes resistant to make changes on the model/the design and has a tendency to freeze the concept. As one of the most important reasons for premature fixation, Utterback (2006: 225) also asserted that use of CAD too early in the design process leads the designer to focus on details. The parts definition, geometric specification and high level of precision make CAD model more exact. The exactness of CAD may limit the designer's ability to make lateral interpretations and create an inconsistency between the creative impulse and the input needed to activate digital commands (Liem, 2012: 2). 
www.mtddergisi.com

ULUSLARARASI HAKEMLİ TASARIM VE MIMARLIK DERGISİ

Eyül / Ekim / Kasım / Aralık Yıl: 2018 Sayı: 15 Sonbahar Kıș Dönemi

INTERNATIONAL REFEREED JOURNAL OF ARCHITECTURE AND DESIGN

September / October / November / December Year: 2018 Number: 15 Autumn Winter Semester ID:324 K:433

ISSN Print: 2148-4880 Online: 2148-8142

(ISO 18001-OH-0090-13001706 / ISO 14001-EM-0090-13001706 / ISO 9001-QM-0090-13001706 / ISO 10002-CM-0090-13001706) (Marka Patent No / Trademark)

(2015/04018 - 2015/GE/17595)

In 2009, Robertson and Radcliffe conducted an extensive online survey with 212 CAD users in order to confirm previously identified effects. The results show that bounded ideation occurs relatively infrequently but circumscribed thinking and premature fixation are quiet widespread in design practice (Robertson, et al., 2009: 136-146).

Salman and Laing (2014: 22) conducted a protocol study in order to investigate the impact of computer-aided architectural design programs on conceptual design in an educational context. According to the results of the study, it was observed that CAD was used for three main purposes in the educational context: conceptual, informative, and presentation. Stating that CAD became more and more integral to the conceptual design process, Lee and Yan (2016: 53, 71) proposed that "CAD should be used for ideation only after its usage has been well-acquired by the user" as a result of their study focusing on user ideation. Otherwise, novice users have the risk of adapting their ideas to their limits on the program and in this case, the modeling tool only leads to cognitive loads and remain behind the manual drawing. The results of the recent study, focusing on comparing CAD vs hand drawing by measuring brain activities (the cerebral blood flow) of the 16 participants when generating ideas, showed that "the significant difference of the qualitative assessment between the hand drawing and computer operation could not be confirmed, and the computer operation activates more channels (brain regions), especially in the right prefrontal cortex, than the hand drawing (Kato et al., 2018: 43).

Veisz, et al. (2012: 317-335) conducted a survey with both experienced and novice professionals and asked them whether CAD tools should be used for idea generation or not. Experienced professionals participating in the study were five educators who have 5 to 20 years of experience teaching CAD to college students and two industry professionals who are an engineering director and a senior engineer with a minimum of 18 years of industry experience. Novice professionals participating in the study were two educators who are post-graduate students (one master's level and one Ph.D. level) who have assisted in teaching a solid modeling course for less than 2 years and two mechanical engineers with less than 5 years industry experience in design and manufacturing companies. Researchers aimed to see whether the experienced and inexperienced professionals have consensus on their opinion and attitudes towards the subject. Their results showed that experienced educators reached the general consensus that CAD should not be used for idea generation. In contrast, novice educators responded that CAD should be used at this stage. The opin- 
www.mtddergisi.com

ULUSLARARASI HAKEMLI TASARIM VE MIMARLIK DERGISİ

Eyül / Ekim / Kasım / Aralık Yıl: 2018 Sayı: 15 Sonbahar Kıș Dönemi

INTERNATIONAL REFEREED JOURNAL OF ARCHITECTURE AND DESIGN

September / October / November / December Year: 2018 Number: 15 Autumn Winter Semester ID:324 K:433

ISSN Print: 2148-4880 Online: 2148-8142

(ISO 18001-OH-0090-13001706 / ISO 14001-EM-0090-13001706 / ISO 9001-QM-0090-13001706 / ISO 10002-CM-0090-13001706) (Marka Patent No / Trademark)

(2015/04018 - 2015/GE/17595)

ion of industry professionals varied depending on the duration of their experience. While novice industry professionals agreed that CAD should be used in the idea generation phase, experienced industry professionals did not completely agree for or against the use of CAD but instead stated some concerns of using CAD during idea generation. Researchers stated that "the majority of today's highly experienced engineers were educated prior to the widespread availability of advanced CAD programs and solid modeling packages. This led to designers completing the conceptual and embodiment design phase through sketching and performing manual calculations" (Veisz, et al., 2012: 318). This, can be interpreted as an important reason for the differences of opinion of professionals. It is also noteworthy that the experienced experts who continue to actively work in the sector do not have as clear negative view as the experienced educators.

\section{Creativity}

"Creative", as an adjective, can be used to attribute a person who is the creator of a thing or to refer to ideas, concepts or products created by a person. There are many different perspectives in terms of defining creativity, some of which are summarized by Batey (2012: 57) as follows:
- person-centered view: assessing creativity with reference to trait attributes, like intelligence or personality

- process-centered view: assessing creativity with reference to problem-solving

- environment-centered view: will focus on the climate for creativity.

Over the last decade, a new approach, product-oriented, has dominated others and general agreement was reached on the following definition: "creativity involves the production of novel, useful products" (Mumford, 2003: 107). This indicates that advocates of this approach will look to define creativity in terms of the outputs or products of an individual. Then, by proxy, the person who produced the novel and useful product will be deemed creative. Since the 1960s, different approaches have been proposed to measure creativity. The most widely accepted approach in the field has emerged as a consequence of the preliminary efforts of J. P. Guilford and E. P. Torrance to a large extent (Sternberg, 2006: 87). Guilford identified four measures of a person's creativity as fluency, flexibility, originality, and elaboration (1956: 267-293). Torrance has developed a standardized measurement tool of creativity called Torrance Test of Creative Thinking (TTCT). Creativity is regarded as the ability to produce ideas in response to a given problem or stimulus in 
the TTCT (Hokanson, 2007: 4). The test battery developed in 1966 consists of "verbal" and "figural" parts. There are 10 sub-tests in total, seven in the verbal section and three in the figural section. The sub-tests in the verbal section include the following activities: asking questions, predicting causes, predicting results, product development, unusual uses, unusual questions, "assume that ...". The subtests in the figural section include activities such as composing a drawing (one closed shape as a stimulus), finishing a drawing (open shapes as stimuli), composing different drawings based on sets of parallel lines or circles as stimuli (Aslan, 2001: 24).

An example of the figural TTCT application based on sets of circles as stimuli, and results are given in Figure 1. This example was used as a reference while designing the data collection methodology. In the TTCT, participants are given blank circles as stimuli and they are asked to sketch at a given time period by accepting these circles as the starting point. The scoring of the test was based on Guilford's four divergent thinking measures. Each measure can be associated with creative output in the context of a prompt that requires a series of responses. The outputs of the test are evaluated through their:

- fluency (how many responses were produced),

- flexibility (how many types of responses were produced),

- originality (how original/unusual were the responses) and

- degree of elaboration (how detailed were the responses).

Accordingly, when the results of the following test are evaluated, it can be concluded that Anna has the highest degree of fluency by performing the greatest number of sketches, and that Benji has the highest degree of flexibility by making the greatest variety of sketches. Darlene has the highest degree of originality by drawing two different types that none of the participants have drawn and Eric has the highest degree of detailing by sketching more detail than the others, despite the same type in the three outputs. 


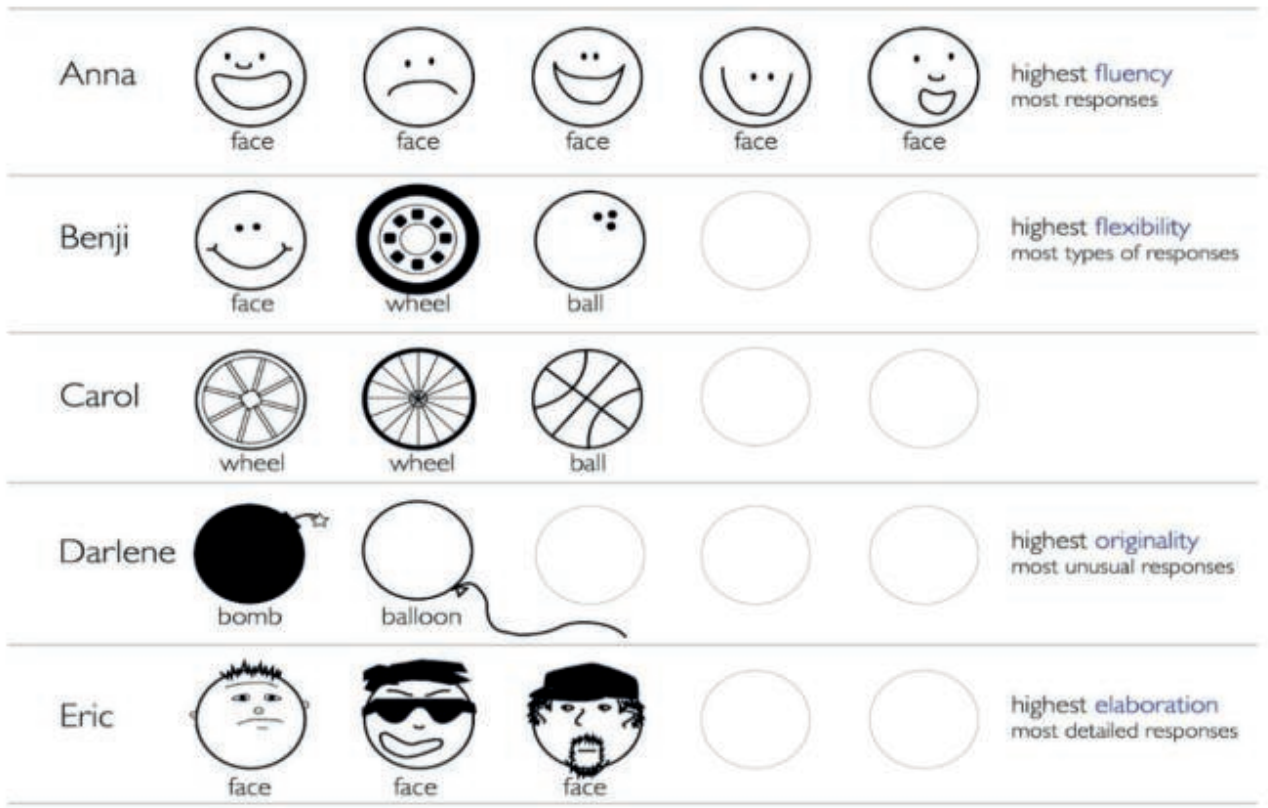

Figure 1. Example of TTCT Application and Results ${ }^{1}$

\section{METHODOLOGY}

The research method has an empirical basis, which is inspired by the approach of the Figural Torrance Test of Creative Thinking. In this study, the identified product definitions were used as stimuli. Participants of the twostage empirical study were asked to generate as many ideas as possible to a given small design problem for each stage. While generating design ideas, they were required to use hand sketching at the first stage and CAD modeling at the second.

$1 \frac{\text { http://www.senseandsensation.com/2012/03/ }}{\text { assessing-creativity.html }}$

\section{Product Definition Selection}

When selecting product definitions, it was considered that the empirical study sessions will be carried out in a limited time period. Decorative vase and decorative candle holder were identified as the two product definition for their familiarity and their relatively low complexity. These criteria, which are considered in the selection of products to be suitable for the short design task, had been tried to be valid at the same level for two different product decisions. The participants were asked to focus on aesthetics and form rather than functional differentiation or innovation 

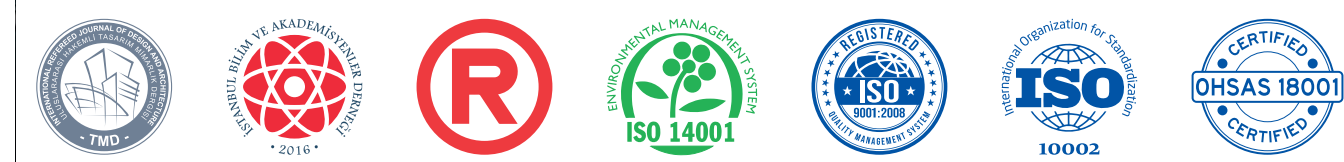

MTD

www.mtddergisi.com

ULUSLARARASI HAKEMLİ TASARIM VE MIMARLIK DERGISİ

Eyül / Ekim / Kasım / Aralık Yıl: 2018 Sayı: 15 Sonbahar Kış Dönemi

INTERNATIONAL REFEREED JOURNAL OF ARCHITECTURE AND DESIGN

September / October / November / December Year: 2018 Number: 15 Autumn Winter Semester ID:324 K:433

ISSN Print: 2148-4880 Online: 2148-8142

(ISO 18001-OH-0090-13001706 / ISO 14001-EM-0090-13001706 / ISO 9001-QM-0090-13001706 / ISO 10002-CM-0090-13001706) (Marka Patent No / Trademark)

(2015/04018 - 2015/GE/17595)

because the evaluation of ideas will focus on the form of the products. No restrictions related to production methods and material preferences were introduced.

\section{Participant Sampling}

When deciding the participant sampling of the study, the results of the survey conducted by Veisz, et al. (2012: 317-335) had been taken into consideration. According to their results, experienced designers have a tendency to be generally opposed to the use of CAD while novice designers agreed that $\mathrm{CAD}$ should be used in the idea generation phase. Considering this, the empirical study was designed to be conducted with new generation designers. The participants were primarily chosen from people that the three researchers had personal communications with, as well as their references. The criteria for the participant selection are as follows.

- The participants should be actively working in the new product development process, from concept development to production.

- Participants should be actively using both hand sketching and CAD modeling in product design processes.

- Participants should have less than ten years of industry experience.
In total, 20 designers (10 women and 10 men) participated in the study. Their industry experience ranged from 1 year to 10 years with a mean of 4,5 years. 8 of the participants are working in the design department of a corporate firm while 12 of them are working in design consultancies. The sectors in which the designers working in the corporate firm include small household appliances, consumer electronics, heavy construction equipment, furniture, medical devices, lighting and home accessories. Design consultancy firms, where 12 participants work, serve a wide range of sectors, depending on their work requirement.

\section{Implementation of the Study}

In a total 40 (2 tests $\times 20$ participants) idea generation sessions were carried out. Each individual session lasted for 60 minutes in total. Time given for each product definition was $30 \mathrm{~min}$. Given the nature of the tasks, half an hour was considered a reasonable time to produce enough conceptual solutions but preventing their refinement (Stones \& Cassidy, 2010: 446).

The sessions were arranged in a way that each participant was asked to study the two products according to a predefined order to limit the 'order effect' (Krosnick, et. al., 1987: 202). That is, the participants developing on candle holder in the first stage studied on the vase in the second stage, or vice versa. For 
MTD

www.mtddergisi.com

ULUSLARARASI HAKEMLI TASARIM VE MIMARLIK DERGISİ

Eyül / Ekim / Kasım / Aralık Yıl: 2018 Sayı: 15 Sonbahar Kıș Dönemi

INTERNATIONAL REFEREED JOURNAL OF ARCHITECTURE AND DESIGN

September / October / November / December Year: 2018 Number: 15 Autumn Winter Semester ID:324 K:433

ISSN Print: 2148-4880 Online: 2148-8142

(ISO 18001-OH-0090-13001706 / ISO 14001-EM-0090-13001706 / ISO 9001-QM-0090-13001706 / ISO 10002-CM-0090-13001706) (Marka Patent No / Trademark)

(2015/04018 - 2015/GE/17595)

the second stage of the study, the participants were free to choose whichever CAD software that they felt more comfortable with. At the end of the first stage, sketched papers were received, and at the end of the second stage, CAD files were received. Each session with each participant was carried out separately.

A supportive questionnaire was designed to provide guidance while interpreting the results of the empirical study. After the implementation of the experimental study, participants were asked to answer several questions about the way of use of design tools in the idea generation phase of design processes and comments on their own competencies.

\section{Analysis of the Findings}

At the last part of the study, the design alternatives gathered from both stages were evaluated comparatively by 20 design experts including 10 educators and 10 practitioners. They were selected by considering convenient accessibility and proximity to the researchers. Educators are working in Gazi University and Attlım University, Department of Industrial Design. Practitioners are product designers with at least 10 years of industry experience in various industries like medical equipment, office furniture, defense industry.

Experts' assessments were made over three of the four measures of creativity: flexibility, originality, and elaboration through a 7-point
Likert Scale (from 1 indicating 'not flexible/ original/elaborate at all' to 7 'very flexible/ original/elaborate'). Fluency, one of Guilford's four measures and focused on the number of ideas produced, was excluded from the scope of the study. Rather than the number of ideas generated, the variety of ideas produced was considered more meaningful in the context of product design.

As the sizes of both participant and evaluator samples are less than 30 and samples of the 2 experiments are matched pairs, Wilcoxon signed-rank test is preferred for analyzing the findings, which is suitable for non-parametric paired-samples. Wilcoxon test highlighted the significance level of the changing condition on the creativeness variables.

Descriptive statistics were used to interpret the test results. Frequencies and descriptives of the supportive questionnaire are showing demographics and self-evaluation of their own competencies by the participants. Besides exploring the distribution of their abilities, these self-evaluations were used to find out influences of sketching/CAD skills on positive/negative signs.

\section{FINDINGS}

This section begins with the descriptive analysis of the supportive questionnaire and continues with the examples of product ideas produced by participants during the empiri- 
cal study. Then, the distribution of experts' evaluation, and Wilcoxon test results for each creativity dimension are given.

\section{Results of the Supportive Questionnaire}

Participants were asked whether they use 3D CAD modeling in the idea generation phase of their professional design processes. As shown in the Figure 2, CAD modeling is used as an idea generation tool by all the participants in their professional design processes with varying intensity of use.

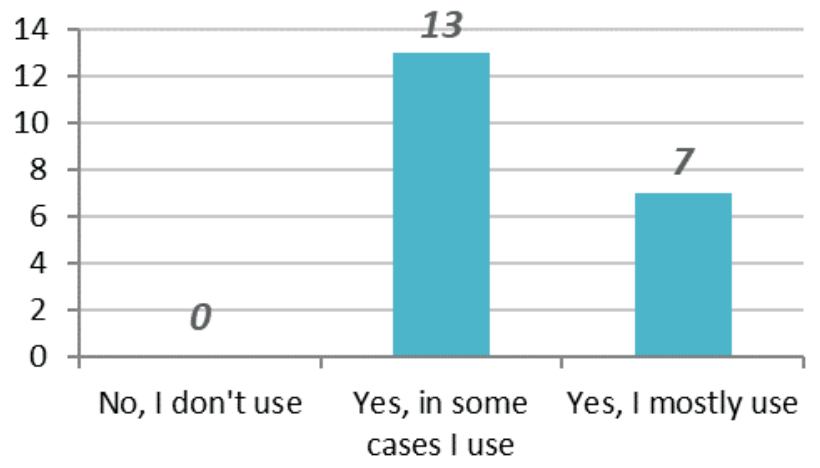

Figure 2. Participants' Answers about CAD Usage in the Idea Generation Phase

They were free to choose the CAD software that they would use in the second stage of the idea generation study. Distribution of their selection related to CAD software is given in the Figure 3.

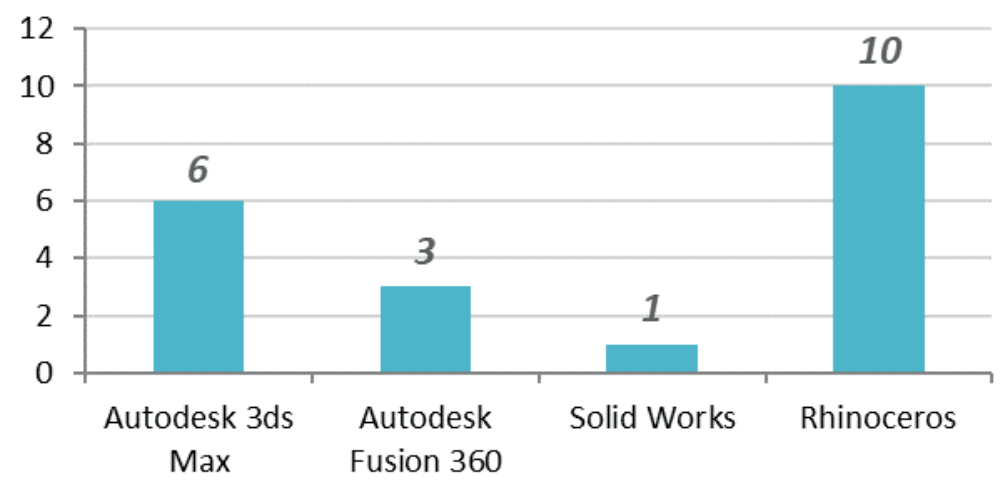

Figure 3. Distribution of CAD Software Used in the Study 


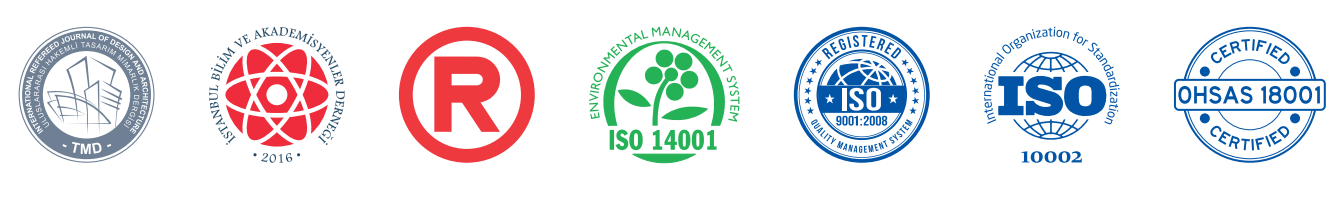

MTD

www.mtddergisi.com

ULUSLARARASI HAKEMLI TASARIM VE MIMARLIK DERGISI

Eyül / Ekim / Kasım / Aralık Yıl: 2018 Sayı: 15 Sonbahar Kıș Dönemi

INTERNATIONAL REFEREED JOURNAL OF ARCHITECTURE AND DESIGN

September / October / November / December Year: 2018 Number: 15 Autumn Winter Semester ID:324 K:433

ISSN Print: 2148-4880 Online: 2148-8142

(ISO 18001-OH-0090-13001706 / ISO 14001-EM-0090-13001706 / ISO 9001-QM-0090-13001706 / ISO 10002-CM-0090-13001706) (Marka Patent No / Trademark)

(2015/04018 - 2015/GE/17595)

Participants were asked to evaluate their overall competence in CAD modeling and hand sketching. They rated their level of competence in 7-point Likert scale. The results show that 75 percent of participants (15) considered themselves more competent in CAD modeling than hand sketching (Figure 4). Notably, 2 participants who evaluated themselves as better in hand sketching, mentioned that they mostly use CAD tools in idea generation. Participant 17 stated that "I can produce ideas and forms faster and I can develop more alternatives much faster with hand sketching but I prefer to use CAD programs in the concept phase to study the details of ideas from perspective views and to make experiments on raw ideas. I can detail concepts and ideas faster by modeling with CAD. In this way, I can speed up my decision-making process." Participant 18 emphasized that he prefer cad modeling, especially when working on more fluid and amorphous forms. It was comprehended that even if some designers are better at hand sketching, they still prefer or perhaps have to use CAD tools for certain circumstances while generating concepts

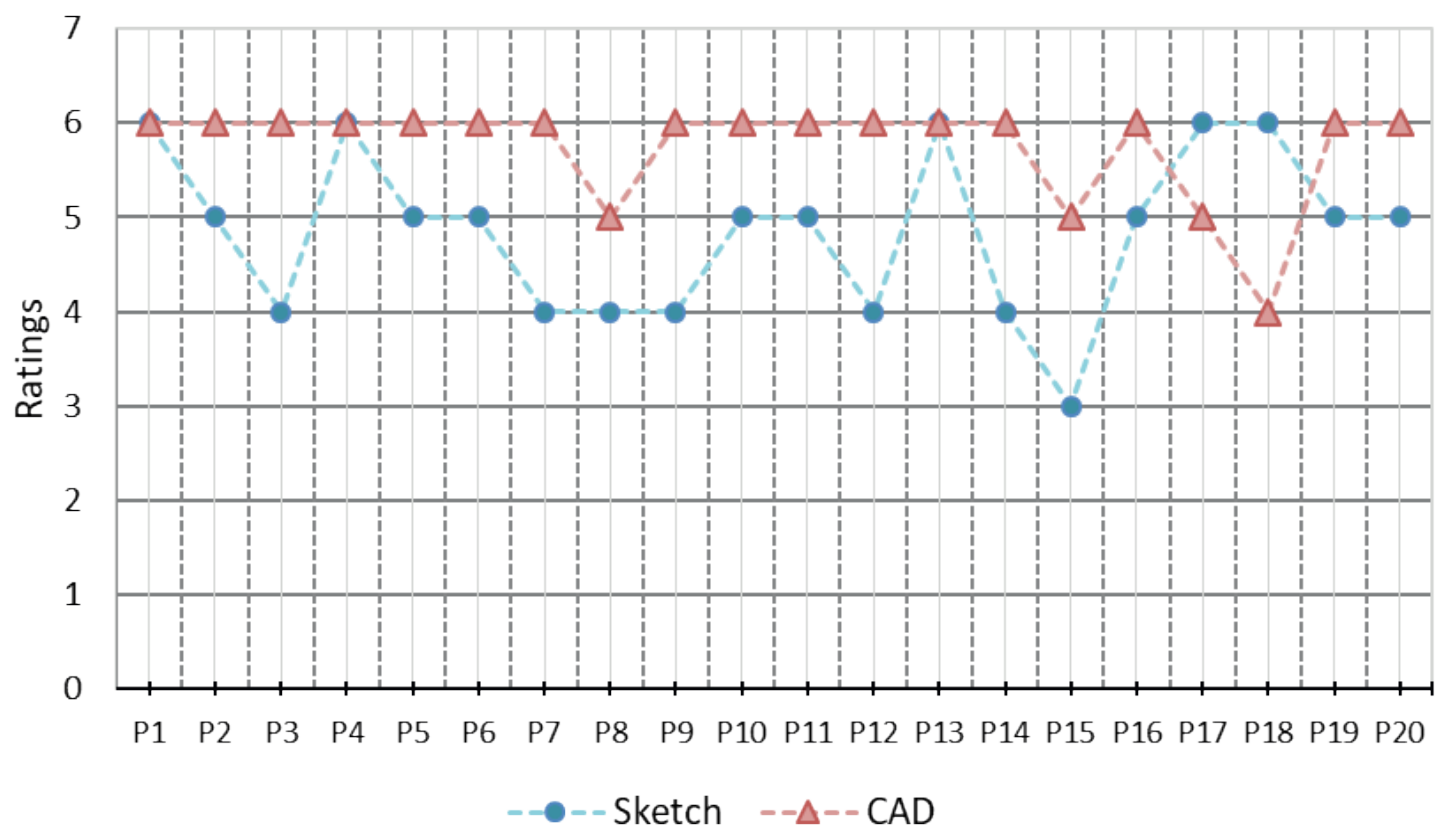

Figure 4. Participants' Self-Evaluations on Their Competence Related to Hand Sketching and CAD Modeling 

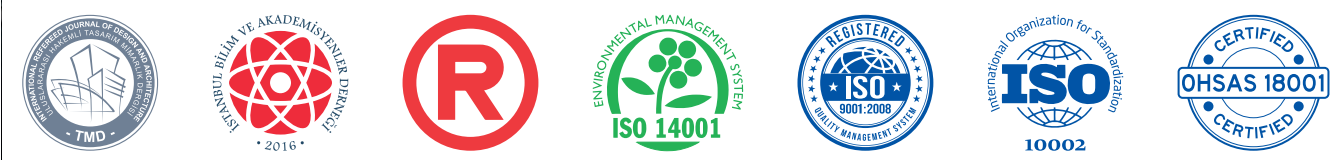

MTD

www.mtddergisi.com

ULUSLARARASI HAKEMLİ TASARIM VE MIMARLIK DERGISİ

Eyül / Ekim / Kasım / Aralık Yıl: 2018 Sayı: 15 Sonbahar Kıș Dönemi

INTERNATIONAL REFEREED JOURNAL OF ARCHITECTURE AND DESIGN

September / October / November / December Year: 2018 Number: 15 Autumn Winter Semester ID:324 K:433

ISSN Print: 2148-4880 Online: 2148-8142

(ISO 18001-OH-0090-13001706 / ISO 14001-EM-0090-13001706 / ISO 9001-QM-0090-13001706 / ISO 10002-CM-0090-13001706) (Marka Patent No / Trademark)

$(2015 / 04018-2015 / G E / 17595)$

\section{Results of the Empirical Study}

Several examples of product ideas generated by hand sketching and CAD modeling at the end of the study are given in the Figure 5 below.

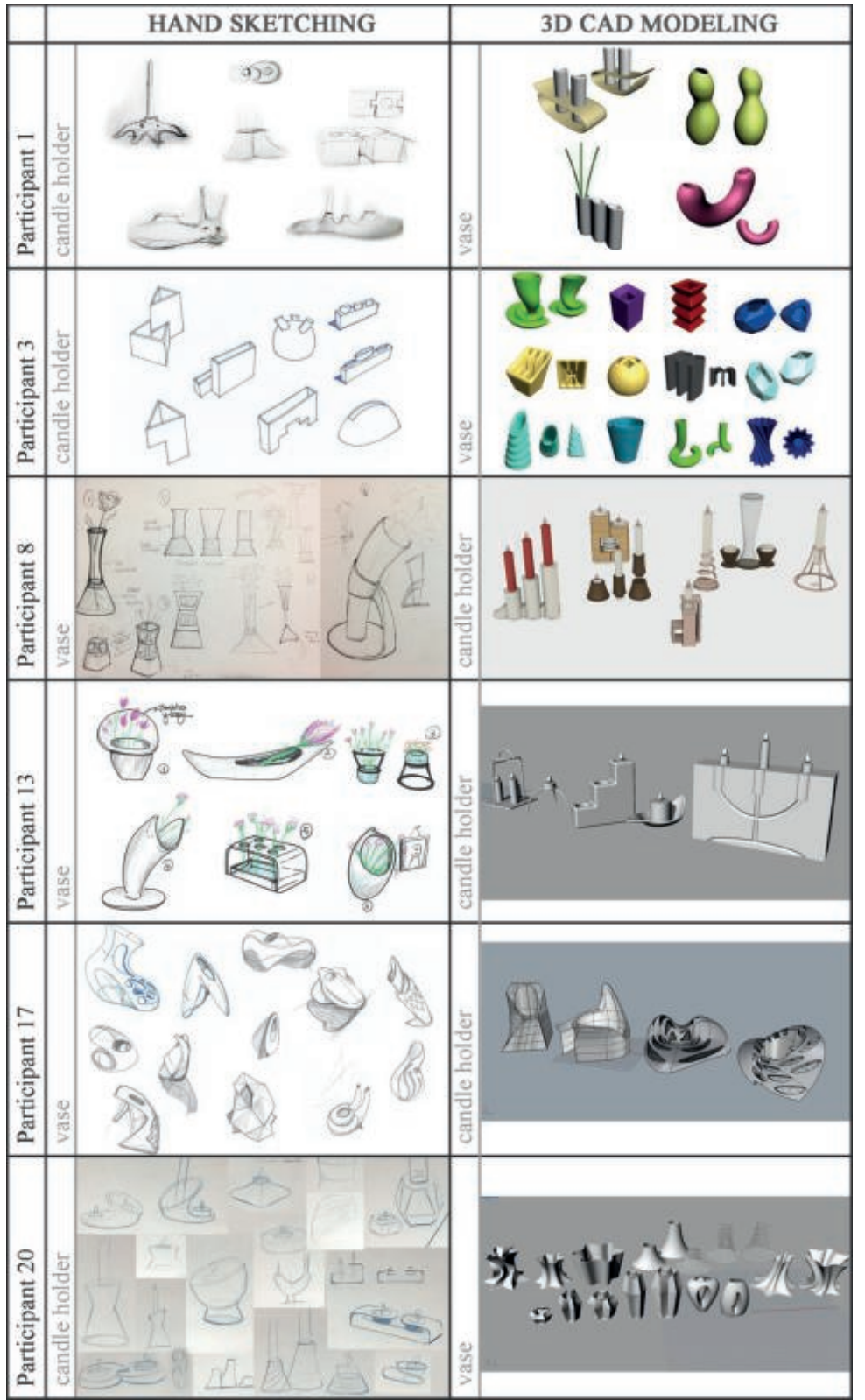

Figure 5. Examples of the Product Ideas Generated by Participants 


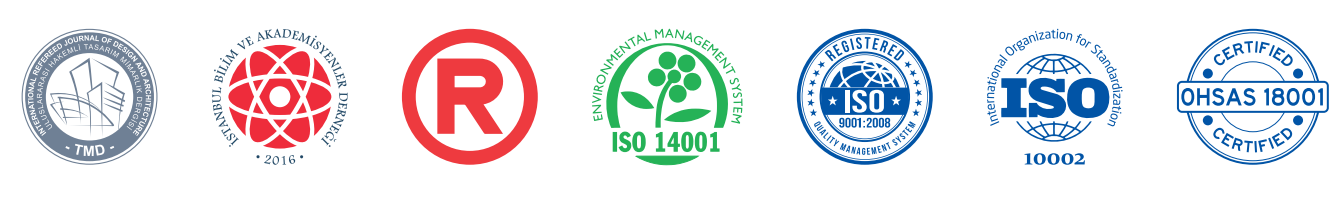

MTD

www.mtddergisi.com

ULUSLARARASI HAKEMLİ TASARIM VE MIMARLIK DERGISI

Eyül / Ekim / Kasım / Aralık Yıl: 2018 Sayı: 15 Sonbahar Kış Dönemi

INTERNATIONAL REFEREED JOURNAL OF ARCHITECTURE AND DESIGN

September / October / November / December Year: 2018 Number: 15 Autumn Winter Semester ID:324 K:433

ISSN Print: 2148-4880 Online: 2148-8142

(ISO 18001-OH-0090-13001706 / ISO 14001-EM-0090-13001706 / ISO 9001-QM-0090-13001706 / ISO 10002-CM-0090-13001706)

(Marka Patent No / Trademark)

(2015/04018-2015/GE/17595)

Each individual solution gathered from both stages was evaluated comparatively by 20 design experts (10 educators and 10 practitioners). They were asked to rate how flexible/ original/elaborate are the solutions through a 7-point Likert Scale (from 1 indicating 'not flexible/original/elaborate at all' to 7 'very flexible/original/elaborate'). For measuring flexibility, they were asked to question how many different types of ideas were produced. For originality, they were asked to consider how original/unusual the product ideas are. For elaboration, they were asked to evaluate the level of detail of the ideas put forward.

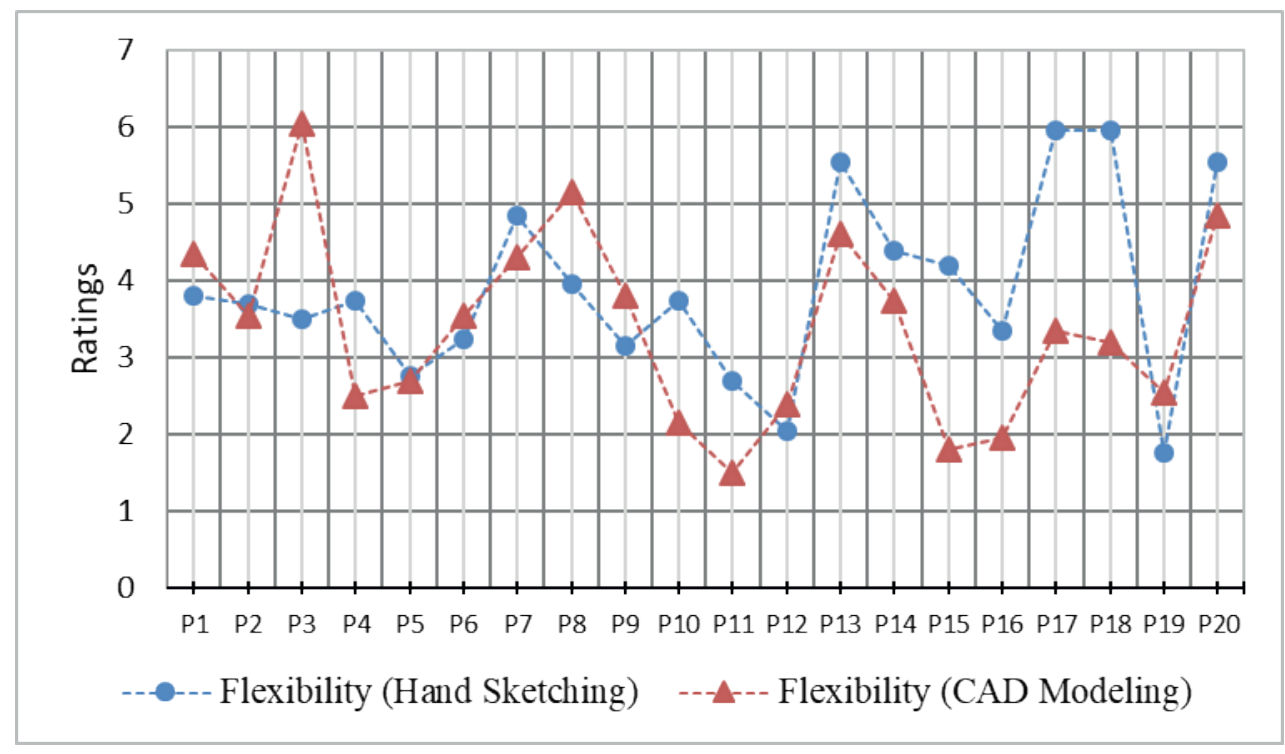

Figure 6. Experts' Evaluation Ratings on Flexibility

The mean value $(3,8950)$ of the ratings for the ideas generated by the hand sketching was higher than the mean value $(3,4025)$ of the ratings for the ideas generated by CAD modeling in terms of flexibility. However, when ratings examined individually, it was seen that the ideas by seven participants generated using CAD modeling were evaluated as more flexible than the ideas generated using hand sketching (Figure 6). In order to test the significance of the difference between evaluation ratings, Wilcoxon Signed Ranks Test was performed. The results of the test can be seen in the Table 1. Accordingly, there was no statistically significant difference between the experts' evaluation ratings in terms of flexibility $(Z=-1,662 ; p=0,097>0,05)$. 


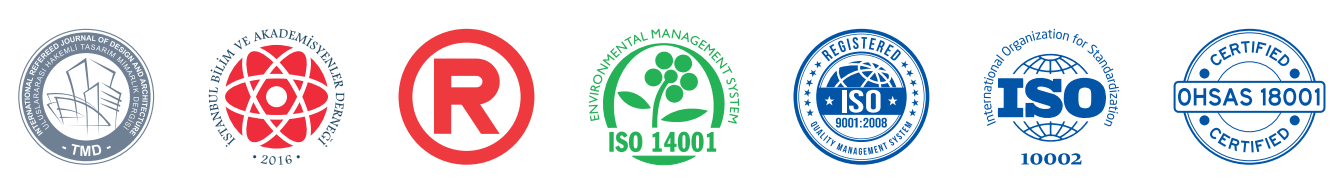

MTD

www.mtddergisi.com

ULUSLARARASI HAKEMLİ TASARIM VE MIMARLIK DERGİSI

Eyül / Ekim / Kasım / Aralık Yıl: 2018 Sayı: 15 Sonbahar Kış Dönemi

INTERNATIONAL REFEREED JOURNAL OF ARCHITECTURE AND DESIGN

September / October / November / December Year: 2018 Number: 15 Autumn Winter Semester ID:324 K:433

ISSN Print: 2148-4880 Online: 2148-8142

(ISO 18001-OH-0090-13001706 / ISO 14001-EM-0090-13001706 / ISO 9001-QM-0090-13001706 / ISO 10002-CM-0090-13001706) (Marka Patent No / Trademark)

$(2015 / 04018-2015 / G E / 17595)$

Table 1. Wilcoxon Signed Ranks Test Results for Flexibility

\begin{tabular}{llllll} 
Flexibility & N & Mean Rank & Sum of Ranks & Z & P \\
\cline { 1 - 4 } Negative Ranks & $13^{\mathrm{x}}$ & 11,50 & 149,50 & \\
\cline { 1 - 5 } Positive Ranks & $7^{\mathrm{y}}$ & 8,64 & 60,50 &, 097 \\
\cline { 1 - 3 } Ties & $0^{\mathrm{z}}$ & - & - &
\end{tabular}

a. Based on positive ranks.

b. Based on negative ranks.

x. flexibility_CAD modeling $<$ flexibility hand sketching y. flexibility_CAD modeling > flexibility_ hand sketching

z. flexibility_CAD modeling $=$ flexibility_ hand sketching

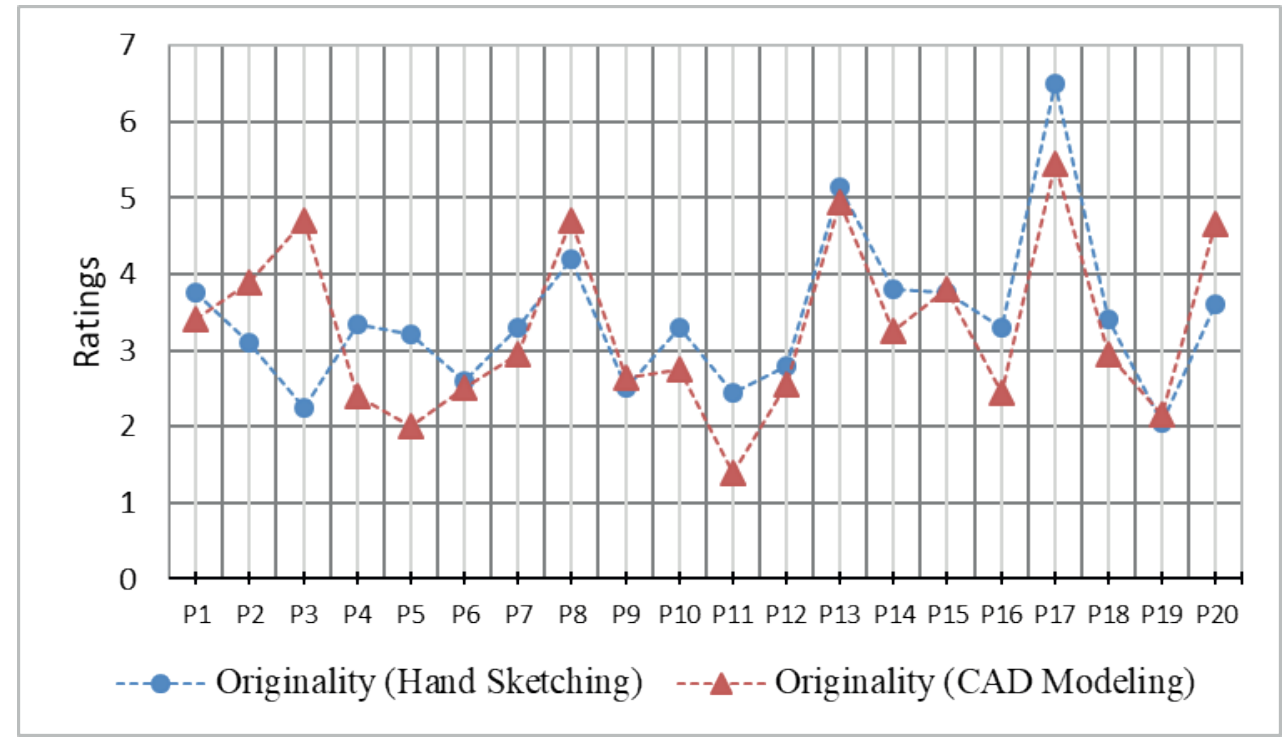

Figure 7. Experts' Evaluation Ratings on Originality

Experts' evaluation ratings on originality can be seen in the Figure 7. While the mean value of the ratings for the ideas generated by the hand sketching is 3,4175 , the mean value of the ratings for the ideas generated by CAD modeling is 3,2775. Most of the product ideas generated by hand sketching were evaluated more original compared with CAD-produced product ideas. However, no statistically significant difference was found between the experts' evaluations in terms of originality according to the Wilcoxon Signed Ranks Test results given in Table $2(Z=-1,401 ; p=0,161>$ $0,05)$. 


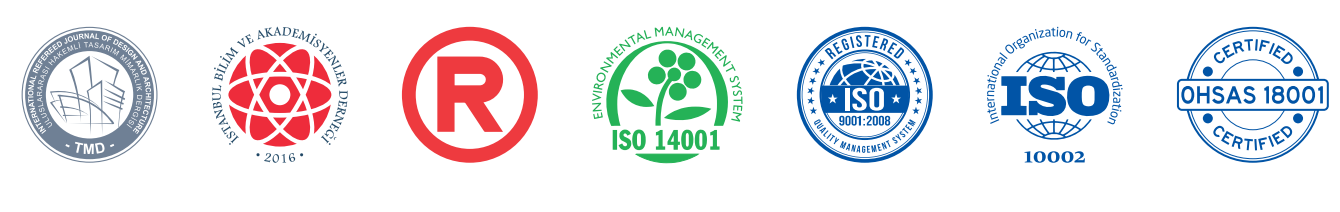

MTD

www.mtddergisi.com

ULUSLARARASI HAKEMLİ TASARIM VE MIMARLIK DERGİII

Eyül / Ekim / Kasım / Aralık Yıl: 2018 Sayı: 15 Sonbahar Kıș Dönemi

INTERNATIONAL REFEREED JOURNAL OF ARCHITECTURE AND DESIGN

September / October / November / December Year: 2018 Number: 15 Autumn Winter Semester ID:324 K:433

ISSN Print: 2148-4880 Online: 2148-8142

(ISO 18001-OH-0090-13001706 / ISO 14001-EM-0090-13001706 / ISO 9001-QM-0090-13001706 / ISO 10002-CM-0090-13001706) (Marka Patent No / Trademark)

(2015/04018 - 2015/GE/17595)

Table 2. Wilcoxon Signed Ranks Test Results for Originality

\begin{tabular}{llllll} 
Originality & N & Mean Rank & Sum of Ranks & Z & P \\
\hline Negative Ranks & $13^{\mathrm{x}}$ & 10,96 & 142,50 & $-1,401^{\mathrm{a}}$ &, 161 \\
\cline { 1 - 4 } Positive Ranks & $7^{\mathrm{y}}$ & 9,64 & 67,50 &
\end{tabular}

a. Based on positive ranks.

b. Based on negative ranks.

x. originality_CAD modeling $<$ originality_hand sketching

y. originality_CAD modeling $>$ originality_hand sketching

z. originality_CAD modeling $=$ originality_hand sketching
According to the results of the evaluation ratings, the product ideas of only 4 participants generated using hand sketching were evaluated as more elaborate than the ideas generated by using CAD modeling (Figure $8)$. The mean value $(4,2425)$ of the ratings for the ideas generated by the CAD modeling was higher than the mean value $(3,4025)$ of the ratings for the ideas generated by hand sketching in terms of the degree of detailing.

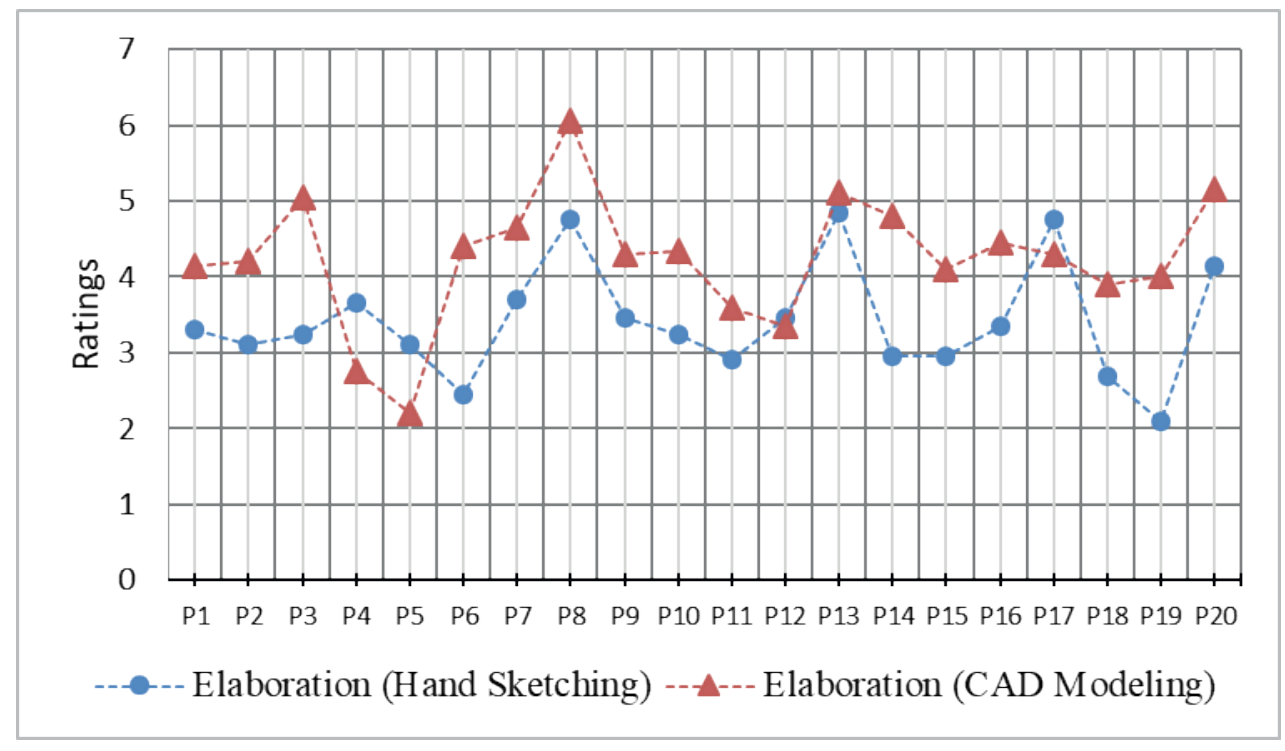

Figure 8. Experts' Evaluation Ratings on Elaboration

The results of the Wilcoxon Signed Ranks Test given Table 3 showed that there was a statistically significant difference between the experts' evaluation ratings in terms of 
elaboration $(\mathrm{Z}=-3,212 ; \mathrm{p}=0,001<0,05)$. Accordingly, it is seen that this difference that arises when the mean rank and the sum of rank are taken into consideration is favored by the positive order, that is, CAD modeling. It was observed that using $\mathrm{CAD}$ modeling clearly increased elaboration skills of most of the participants.

Table 3. Wilcoxon Signed Ranks Test Results for Elaboration

\begin{tabular}{llllll} 
Elaboration & N & Mean Rank & Sum of Ranks & Z & P \\
\cline { 1 - 4 } Negative Ranks & $4^{\mathrm{x}}$ & 4,75 & 19,00 & $-3,212^{\mathrm{b}}$ &, 001 \\
\cline { 1 - 5 } Positive Ranks & $16^{\mathrm{y}}$ & 11,94 & 191,00 &
\end{tabular}

a. Based on positive ranks.

b. Based on negative ranks.

x. elaboration_CAD modeling $<$ elaboration_hand sketching

y. elaboration_CAD modeling > elaboration_hand sketching

z. elaboration_CAD modeling = elaboration_hand sketching
Figure 9 shows the participants' self-evaluations on their competence at CAD and HS (Hand Sketching). Accordingly, most of the participants (15 out of 20) feel that they are more competent at CAD. While there are three participants who see themselves in the same competence level at CAD and HS, there are two participants who feel more competent at HS.

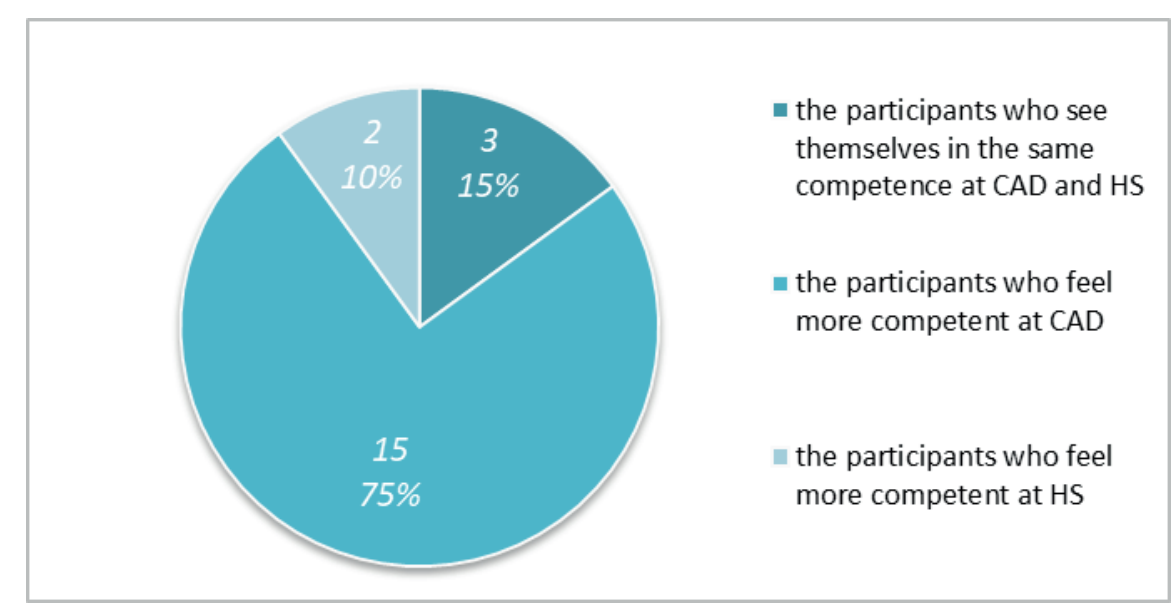

Figure 9. Distribution of the Number of Participants According to Their Self-Evaluation 
www.mtddergisi.com

ULUSLARARASI HAKEMLI TASARIM VE MIMARLIK DERGİİ

Eyül / Ekim / Kasım / Aralık Yıl: 2018 Sayı: 15 Sonbahar Kıș Dönemi

INTERNATIONAL REFEREED JOURNAL OF ARCHITECTURE AND DESIGN

September / October / November / December Year: 2018 Number: 15 Autumn Winter Semester ID:324 K:433

ISSN Print: 2148-4880 Online: 2148-8142

(ISO 18001-OH-0090-13001706 / ISO 14001-EM-0090-13001706 / ISO 9001-QM-0090-13001706 / ISO 10002-CM-0090-13001706) (Marka Patent No / Trademark)

$(2015 / 04018-2015 / G E / 17595)$

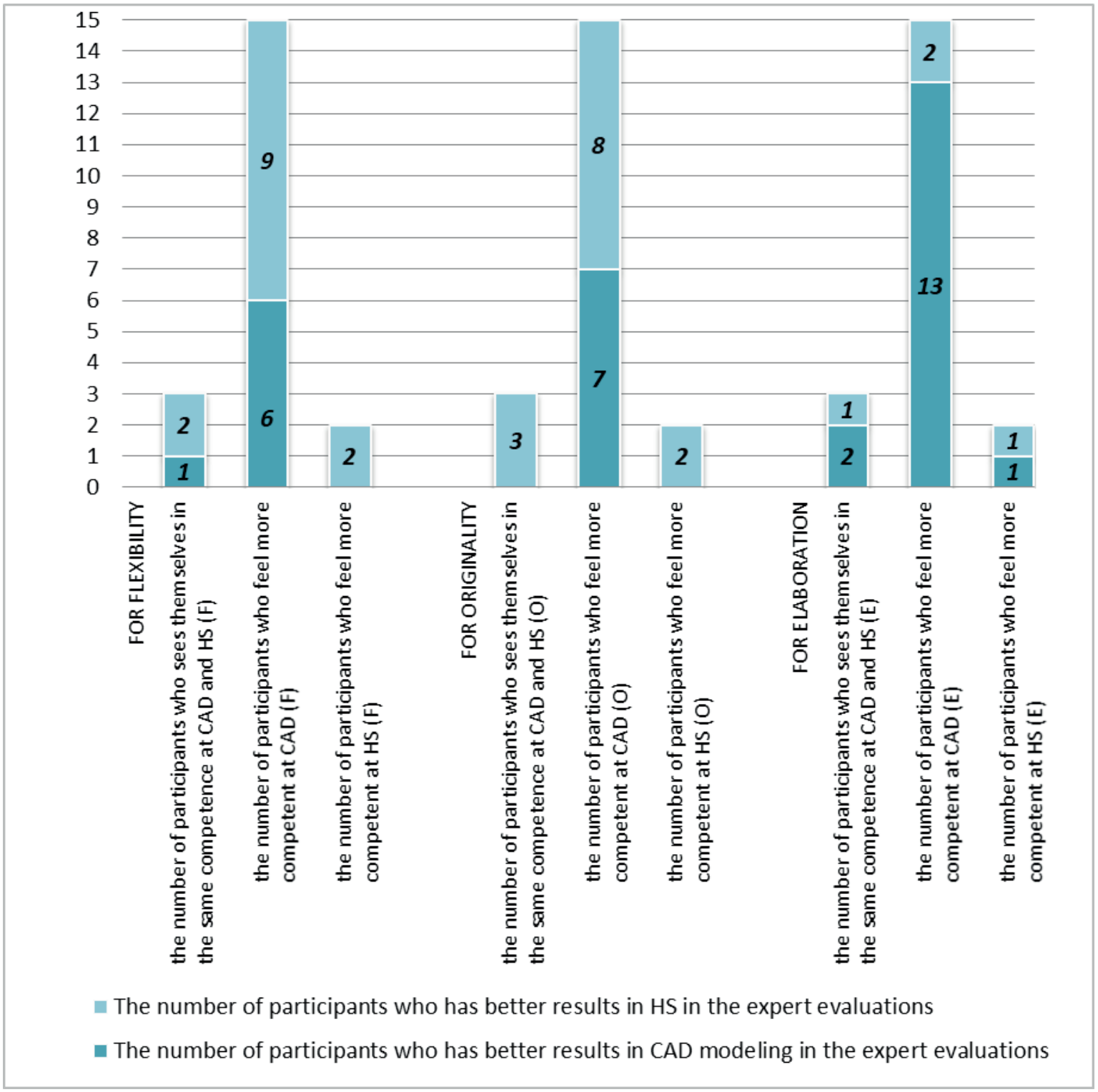

\section{Figure 10. Distribution of the Number of Participants According to Both Self-Evalua-} tions and Expert Evaluations

In Figure 10, the participants' self-evaluations on their competence were tried to be interpreted comparatively with the results of the expert evaluations. Figure consists of 3 sections for 3 creativity dimensions. In each section, the same distribution of 20 participants according to their self-evaluation was given. For each creativity dimension, the dis- 
Www.mtddergisi.com

ULUSLARARASI HAKEMLİ TASARIM VE MIMARLIK DERGİSI

Eyül / Ekim / Kasım / Aralık Yıl: 2018 Sayı: 15 Sonbahar Kış Dönemi

INTERNATIONAL REFEREED JOURNAL OF ARCHITECTURE AND DESIGN

September / October / November / December Year: 2018 Number: 15 Autumn Winter Semester ID:324 K:433

ISSN Print: 2148-4880 Online: 2148-8142

(ISO 18001-OH-0090-13001706 / ISO 14001-EM-0090-13001706 / ISO 9001-QM-0090-13001706 / ISO 10002-CM-0090-13001706) (Marka Patent No / Trademark)

$(2015 / 04018-2015 / G E / 17595)$

tribution of participants according to the expert evaluations was given color coded. There were two types: (1) the number of participants who has better results in hand sketching, and (2) the number of participants who has better results in CAD modeling. As can be seen in the Figure 10, there are 15 participants who believe that they are more competent at CAD than hand sketching. For example, in terms of flexibility, the results by hand sketching of 9 out of 15 participants who thought they were more competent in $\mathrm{CAD}$ were considered to be better by experts. Similarly, in terms of originality, the ideas generated by hand sketching of 8 out of these 15 participants were found more original by experts. Therefore, it is possible to say that there is no direct relationship between self-evaluations and experts' evaluations.

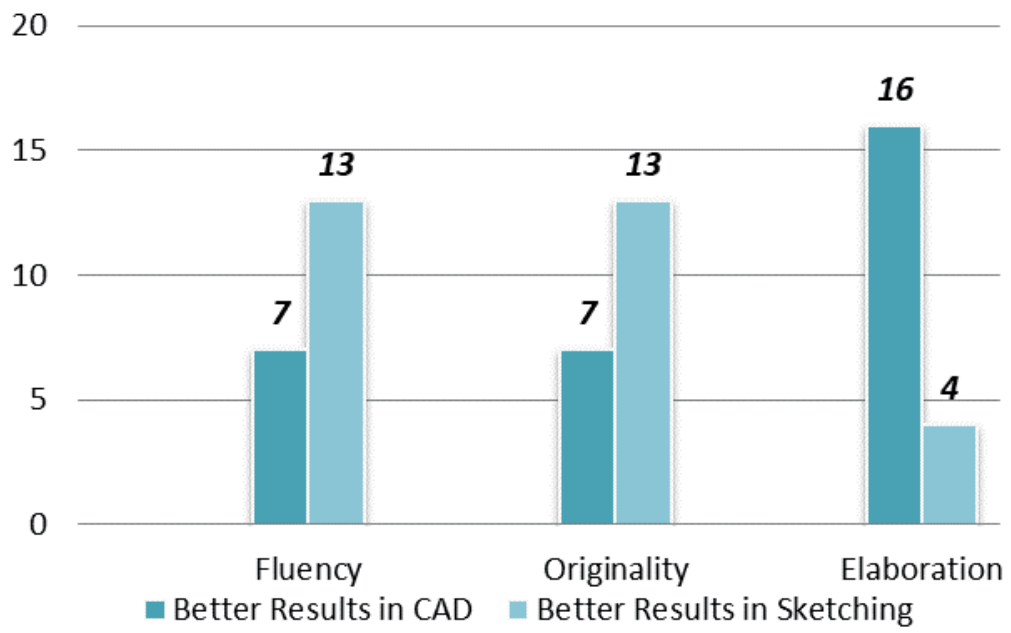

\section{Figure 11. Distribution of the Number of Participants According to Experts' Evaluations for Each Creativity Dimension}

Figure 11 shows the distribution of the number of participants according to expert' evaluations for each creativity dimensions. It was seen that the ideas developed by hand sketching of 13 out of 20 participants were found more flexible and original than the ideas developed by CAD modeling. The ideas gener- ated by CAD modeling of 16 out of 20 participants were found more elaborate.

\section{DISCUSSION}

When the three creativity measures were addressed altogether (Figure 12), it was seen that the use of CAD modeling increased the scores of all three dimensions at 4 participants 
www.mtddergisi.com

ULUSLARARASI HAKEMLI TASARIM VE MIMARLIK DERGİİ

Eyül / Ekim / Kasım / Aralık Yıl: 2018 Sayı: 15 Sonbahar Kıș Dönemi

INTERNATIONAL REFEREED JOURNAL OF ARCHITECTURE AND DESIGN

September / October / November / December Year: 2018 Number: 15 Autumn Winter Semester ID:324 K:433

ISSN Print: 2148-4880 Online: 2148-8142

(ISO 18001-OH-0090-13001706 / ISO 14001-EM-0090-13001706 / ISO 9001-QM-0090-13001706 / ISO 10002-CM-0090-13001706) (Marka Patent No / Trademark)

$(2015 / 04018-2015 / G E / 17595)$

(P3, P8, P9, and P19), the two of three dimensions at 4 participants (P1, P6, P15, P20), and the one of three dimensions at 9 participants (P2, P7, P10, P11, P12, P13, P14, P16, and
P18). Only three of the participants (P4, P5, P17) performed worse on both three dimensions when they used CAD modeling tools.

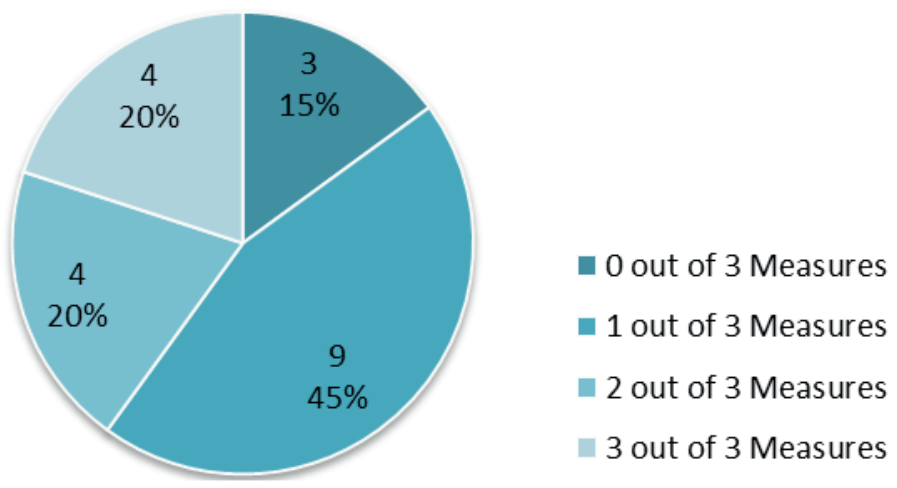

Figure 12. Distribution of Participants According to All Creativity Measures Addressed Together

Hand sketching's ability to enhance flexibility is heavily emphasized in the literature. However, according to the results obtained, even if the negative ranks were higher in quantity (Table 1.), the significance test marked that it is not possible to generalize that CAD negatively affects flexibility. It was seen that the flexibility of individuals could be both affected positively or negatively with the use of CAD modeling (Figure 6.). Similar to the signed ranks of flexibility, the influence of CAD modeling on originality cannot be directly attributed as positive or negative (Table 2). The results showed that CAD usage could affect each designer differently in terms of flexibility and originality (Figure 11). But in terms of elaboration, it is possible to claim that $\mathrm{CAD}$ modeling has a positive influence on detailing (Table 3). Because of the fact that designers when generating ideas with hand sketching can make ambiguous and unfinished doodling even in a single orthographic view but while using CAD modeling they necessarily have to handle product ideas in three dimensions and to elaborate the ideas at a certain level.

Findings mark that, taking $\mathrm{CAD}$ tools as a negative influencer of creativity in design could be prejudiced. Even if previous criticisms such as premature fixation of ideas depending upon CAD usage are probably still valid, negative influences are not statistically generalizable. Almost one-third of partici- 
www.mtddergisi.com

ULUSLARARASI HAKEMLİ TASARIM VE MIMARLIK DERGISİ

Eyül / Ekim / Kasım / Aralık Yıl: 2018 Sayı: 15 Sonbahar Kıș Dönemi

INTERNATIONAL REFEREED JOURNAL OF ARCHITECTURE AND DESIGN

September / October / November / December Year: 2018 Number: 15 Autumn Winter Semester ID:324 K:433

ISSN Print: 2148-4880 Online: 2148-8142

(ISO 18001-OH-0090-13001706 / ISO 14001-EM-0090-13001706 / ISO 9001-QM-0090-13001706 / ISO 10002-CM-0090-13001706) (Marka Patent No / Trademark)

(2015/04018 - 2015/GE/17595)

pants had better scores in flexibility and originality at CAD modeling (Figure 11.). Under controlled conditions established in the scope of this study, it was observed that there is no statistically significant negative influence of CAD on Guilford measures of creativity. On the contrary, 40 percent of the participants/ designers put better results in at least two of the three creativeness dimensions when using CAD tools (Figure 12). More than one-third of the participants generated more original or more flexible ideas. Even the participants who thought that they were better in hand sketching stated that they often use CAD as a tool for idea generation. Also, it was seen that even though some of the participants believed that they are more competent in CAD tools, they had better scores when sketching.

\section{LIMITATIONS}

The most important limitation is the unavoidable artificial nature of the study in terms of design motivations and product definitions. The results obtained from this study were arisen depending on the two determined product definitions. They were selected because of their familiarity and relatively low complexity considering the time limitation of the study. But products designed for the real market by the product designers do not always have these specific characteristics and the nature of the design practice changes as the complexity of the products increases.
Another limitation of the study is that participants use different CAD modeling programs within the scope of the empirical study. The participants were free to choose whichever CAD software that they would like to use. However, different programs have different abilities. Some programs offer a more rigid work environment, while others offer a more flexible environment. This may have slightly influenced the results of the study, but it does not seem very likely to find a large number of participants using the same program with the same competence level. In this empirical study, CAD software is not taken as an independent variable in analysis due to distributed sample sizes are not sufficient to run tests.

\section{CONCLUSION}

It is quite challenging to investigate creativity in the context of product design because of the iterative and complicated nature of the process. However, the degree of creativity can be explored within the relatively controlled conditions. This study has addressed creativity with a product-oriented approach and focused on the idea generation phase of the design process. The aim of this study was to investigate the influence of using 3D CAD modeling tools in the idea generation phase on designers' creativity. In order to provide empirical findings to clarify how the use of CAD tools affects creativity, an empirical study was designed inspired by the approach 

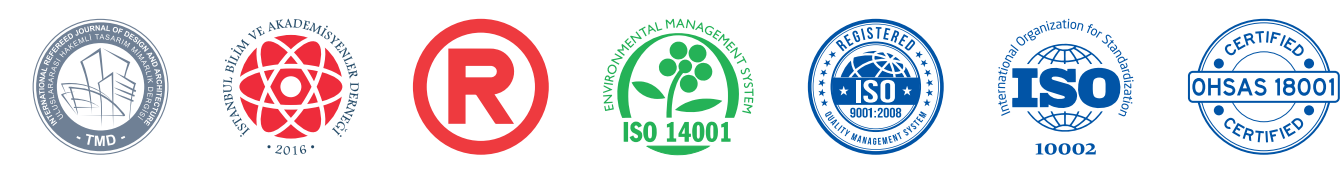

MTD

www.mtddergisi.com

ULUSLARARASI HAKEMLİ TASARIM VE MIMARLIK DERGISI

Eyül / Ekim / Kasım / Aralık Yıl: 2018 Sayı: 15 Sonbahar Kıș Dönemi

INTERNATIONAL REFEREED JOURNAL OF ARCHITECTURE AND DESIGN

September / October / November / December Year: 2018 Number: 15 Autumn Winter Semester ID:324 K:433

ISSN Print: 2148-4880 Online: 2148-8142

(ISO 18001-OH-0090-13001706 / ISO 14001-EM-0090-13001706 / ISO 9001-QM-0090-13001706 / ISO 10002-CM-0090-13001706) (Marka Patent No / Trademark)

(2015/04018-2015/GE/17595)

of the Figural Torrance Test of Creative Thinking. In the two-staged empirical study with 20 designers, participants were expected to develop product ideas using hand sketching and CAD modeling. The product ideas generated were evaluated comparatively by 20 design expert (10 educators and 10 practitioners) considering three of the four Guilford's creativity measures: flexibility, originality, and elaboration.

The results showed that the use of CAD modeling could affect creativity in both a positive and negative way. For the dimensions of flexibility and originality, the product ideas that the participants developed by hand sketching have received better results. For the dimension of elaboration, the product ideas that the participants developed by CAD modeling have received better results. In order to test the significance of the difference between experts' evaluation ratings, Wilcoxon Signed Ranks Test was performed. No statistically significant difference was found between the experts' evaluations in terms of flexibility and originality according to the Wilcoxon Signed Ranks Test results. It was observed that there was a statistically significant difference between the experts' evaluation ratings in terms of elaboration. Therefore, it is not possible to generalize that CAD negatively affects the dimensions of flexibility and originality however it is possible to state that using CAD modeling clearly increased elaboration skills of most of the participants.

It was concluded that the use of CAD modeling cannot be generalized as a negative influencer of creativity. It was observed that CAD softwares could affect creativity in a positive way for any of the three measures. This may be effective in eliminating prejudices regarding the use of CAD modeling as a designing tool in the early stages of the process. This study does not claim that the use of CAD modeling can be considered to be a substitute for sketching in idea generation, however, the fact that CAD can be used as a useful and effective design tool in certain circumstances should not be ignored.

\section{REFERENCES}

ALCAIDE-MARZAL, J., DIEGO-MÁS, J.A., ASENSIO-CUESTA, S., PIQUERAS-FISZMAN, B., (2013). An exploratory study on the use of digital sculpting in conceptual product design. Design Studies, 34(2):264-284

ASLAN, E., (2001). Torrance yaratic1 düşünce testinin Türkçe versiyonu. M.Ü. Atatürk Eğitim Fakültesi Eğitim Bilimleri Dergisi, 14:19-40

BATEY, M., (2012). The measurement of creativity: from definitional consensus to the introduction of a new heuristic 


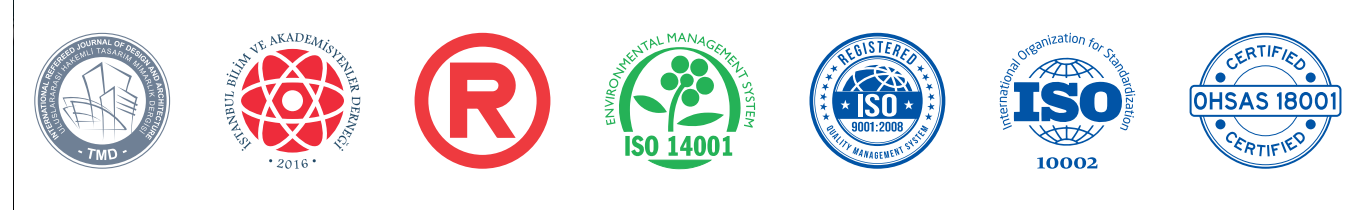

MTD

www.mtddergisi.com

ULUSLARARASI HAKEMLİ TASARIM VE MIMARLIK DERGİSI

Eyül / Ekim / Kasım / Aralık Yıl: 2018 Sayı: 15 Sonbahar Kıș Dönemi

INTERNATIONAL REFEREED JOURNAL OF ARCHITECTURE AND DESIGN

September / October / November / December Year: 2018 Number: 15 Autumn Winter Semester ID:324 K:433

ISSN Print: 2148-4880 Online: 2148-8142

(ISO 18001-OH-0090-13001706 / ISO 14001-EM-0090-13001706 / ISO 9001-QM-0090-13001706 / ISO 10002-CM-0090-13001706) (Marka Patent No / Trademark)

(2015/04018 - 2015/GE/17595)

framework. Creativity Research Journal, 24(1):55-65

BILDA, Z., DEMIRKAN, H., (2003). An insight on designers' sketching activities in traditional versus digital media. Design Studies, 24(1):27-50

BROWN, P. ,(2009). CAD: Do computers aid the design process after all?. Intersect: The Stanford Journal of Science, Technology and Society, 2(1):52-66

BUXTON, B., (2007). Sketching user experiences: getting the design right and the right design. San Francisco: Morgan Kaufmann, p.111

CHARLESWORTH, C., (2007). Student use of virtual and physical modelling in design development-an experiment in 3D design education. The Design Journal, 10(1):35-45

CROSS, N., (2005). Engineering Design Methods: Strategies for Product Design. (Fourth edition). England: John Wiley \&Sons, pp.30-31

CROSS, N., (2006). Designerly ways of knowing. London: Springer-Verlag, pp.7-18

GEDENRYD, H., (1998). How designers work: making sense of authentic cogni- tive activities. Lund, Sweden: Lund University Cognitive Studies, p.4

GUILFORD, J.P., (1956). The structure of intellect. Psychological Bulletin, 53:267293.

GOEL, V., (1995). Sketches of thought. Cambridge, MA: MIT Press, p.197

HÄGGMAN, A., TSAI, G., ELSEN, C., HONDA, T., YANG, M.C., (2015). Connections between the design tool, design attributes, and user preferences in early stage design. Journal of Mechanical Design, 137(7):071408

HOKANSON, B., (2007). By measure: creativity in design. Industry and Higher Education, 21(5): 353-359.

INDUSTRIAL DESIGN INSTITUTE, (2014). A Guide to the Industrial Design Body of Knowledge. (First edition). Philadelphia: Industrial Design Institute, p.16

KATO, T., OTAGIRI, S., NAGAMORI, Y., IZU, Y., (2018). Comparison of brain activities between hand and computer drawings in Finke's pattern generation task. Journal of the Science of Design, 2(2):43-52

KROSNICK, J.A., ALWIN, D.F., (1987). An evaluation of a cognitive theory of response order effects in survey measure- 
ment. Public Opinion Quarterly, 51:201219

LAWSON, B., (1997). How designers think: the design process demystified. Oxford, UK: Butterworth Architecure, pp.281285

LEE, S., YAN, J., (2016). The impact of 3D CAD interfaces on user ideation: A comparative analysis using SketchUp and Silhouette Modeler. Design Studies, 44:52-73

LIEM, A., (2012). Computer aided design as an idea and concept generation tool in the early stages of the design process. In DS 71: Proceedings of NordDesign 2012, the 9th NordDesign conference, Aarlborg University, Denmark. 22-24.08. 2012, p. 2

MUMFORD, M.D., (2003). Taking stock in taking stock. Creativity Research Journal, 15:147-151

PAHL, G., BEITZ, W., (2007). Engineering Design: A Systematic Approach. (Third edition). London; Springer, p.57

ROBERTSON, B.F., WALTHER, J., RADCLIFFE, D.F., (2007). Creativity and the use of CAD tools: lessons for engineering design education from industry. Journal of Mechanical Design, 129(7):753-760
ROBERTSON, B.F., RADCLIFFE, D.F., (2009). Impact of CAD tools on creative problem solving in engineering design. Computer-Aided Design, 41(3):136-146

SALMAN, H.S., LAING, R., CONNIFF, A., (2014). The impact of computer aided architectural design programs on conceptual design in an educational context. Design Studies, 35(4):412-439.

SELF, J.A., (2011). The Use Of Design Tools In Industrial Design Practice. London, UK: PhD Dissertation, Kingston University, pp.64-91

STONES, C., CASSIDY, T., (2010). Seeing and discovering: how do student designers reinterpret sketches and digital marks during graphic design ideation?. Design Studies, 31(5):439-460

STERNBERG, R.J., (2006). The nature of creativity. Creativity Research Journal, 18(1):87-98.

SUWA, M., TVERSKY, B., (2002). How do designers shift their focus of attention in their own sketches? In: Anderson M., Meyer B., Olivier P. (Eds.), Diagrammatic reasoning and representation, London: Springer, pp.241-260

TEMPLE, S., (1994). Thought made visible: the value of sketching. Co-Design Journal, 1:16-25. 


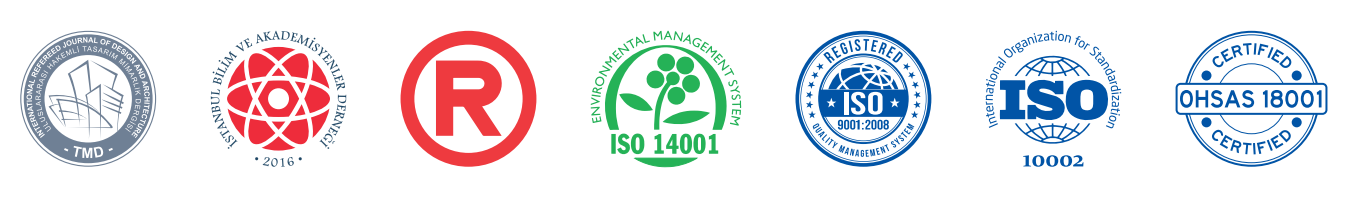

MTD

www.mtddergisi.com

ULUSLARARASI HAKEMLİ TASARIM VE MIMARLIK DERGISİ

Eyül / Ekim / Kasım / Aralık Yıl: 2018 Sayı: 15 Sonbahar Kış Dönemi

INTERNATIONAL REFEREED JOURNAL OF ARCHITECTURE AND DESIGN

September / October / November / December Year: 2018 Number: 15 Autumn Winter Semester ID:324 K:433

ISSN Print: 2148-4880 Online: 2148-8142

(ISO 18001-OH-0090-13001706 / ISO 14001-EM-0090-13001706 / ISO 9001-QM-0090-13001706 / ISO 10002-CM-0090-13001706) (Marka Patent No / Trademark)

(2015/04018 - 2015/GE/17595)

TOVEY, M., DEKKER, K., (1996). Rapid $3 \mathrm{D}$ models from $2 \mathrm{D}$ sketches. Co-Design Journal, 7(09):62-65

UNVER, E., (2006). Strategies for the transition to CAD based 3D design education. Computer-Aided Design and Applications, 3(1-4):323-330

\section{UTTERBACK, J., VEDIN, B.A., ALVA-} REZ, E., EKMAN, S., WALSH, S.S., TETHER, B., et al., (2006). Design-Inspired Innovation. Singapore: World Scientific Publishing, pp.215-227

VEISZ, D., NAMOUZ, E.Z., JOSHI, S., SUMMERS, J.D., (2012). Computeraided design versus sketching: An exploratory case study. AI EDAM, 26(3):317335
WARBURTON, N., (1996). A heuristic model for digitally integrated design. Co-Design Double Issue, (7):22-27

WON, P.H., (2001). The comparison between visual thinking using computer and conventional media in the concept generation stages of design. Automation in Construction, 10(3):319-325

YILDIRIM, T., YAVUZ, A.Ö., INAN, N., (2011). Mimari tasarım eğitiminde geleneksel ve dijital görselleştirme teknolojilerinin karşılaştırılması. Bilişim Teknolojileri Dergisi, 3(3):17-26

\section{INTERNET SOURCES}

http://www.senseandsensation.com/2012/03/ assessing-creativity.html (E.T. 08.01.2018) 